\section{EPS EXECUTIVE COMMITTEE 1982/83}

Council elected as the EPS Executive Committee for the next 12 months the following:

$\begin{array}{ll}\text { President } & \text { J. Friedel, Orsay } \\ \text { Vice-President } & \text { G.H. Stafford, Oxford } \\ \text { Secretary } & \text { E.A. Müller, Geneva } \\ \text { Vice-Secretary } & \text { H. de Waard, Groningen } \\ \text { Treasurer } & \text { D. Kuhn, Innsbruck } \\ \text { Vice-Treasurer } & \text { G. Preparata, Bari } \\ \text { Members } & \text { K.E. Ganzhorn, Stuttgart } \\ & \text { J. Kaczer, Prague } \\ & \text { O.V. Lounasmaa, Espoo } \\ & \text { A. Milojevic, Belgrade } \\ & \text { K.K. Rebane, Tallinn }\end{array}$

\section{EPS TRAVELLING LECTURER 1982}

The programme of the 1982 EPS Travelling Lecturer, Professor Isaac Silvera, has now reached a definite form. The titles of the lectures that Prof. Silvera will give are the following:

1. Atomic Hydrogen: a Quantum Gas at Zero Kelvin.

2. New Phases of Molecular Hydrogen and Deuterium at Ultra High Pressures.

3. The Ultra High Pressure Equation of State of Molecular Hydrogen: Is the Dense Atomic State in Sight?

Apart from a visit to Paris in March, Prof. Silvera's tour will be in two stages:

$\begin{array}{lll}\text { 1. Scandinavian Countries: } & \\ \text { Copenhagen } & \text { 2- } 4 \text { May } & \text { Lecture 1 } \\ \text { Göteborg } & \text { 4- } 6 \text { May } & \text { Lecture 1 } \\ \text { Oslo } & \text { 6- } 7 \text { May } & \text { Lectures 1, 2 } \\ \text { Uppsala } & \text { 8-11 May } & \text { Lecture 2 } \\ \text { Turku } & \text { 11-12 May } & \text { Lectures 1, 2, 3 } \\ \text { Helsinki } & \text { 13-14 May } & \text { Lectures 1, 2, 3 } \\ \text { 2. South and East: } & \\ \text { Genoa } & \text { 23-25 May } & \text { Lecture 3 } \\ \text { Rome } & \text { 25-27 May } & \text { Lecture 1 } \\ \text { Istanbul } & \text { 27-29 May } & \text { to be announced } \\ \text { Tel-Aviv } & \text { 29-1 May-June } & \text { Lectures 1, 2 } \\ \text { Haifa } & \text { 1- 6 June } & \text { Lectures 1, 2 }\end{array}$

Precise times and locations of the lectures will be announced on EPS posters displayed in the relevant areas.

\title{
Revision to the Constitution and By-Laws
}

Following the decisions taken by Council at its meeting in Geneva on 1-2 April 1982 regarding changes to the Constitution and By-Laws, the relevant clauses now read as follows:

Constitution

ARTICLE 4 (Membership)

The following individuals, legal persons or bodies may become Ordinary Members of the Society:

a) individuals who have shown by their contribution to European science, by their professional activity or otherwise, to the Council's satisfaction, that they can further the cause and object of the Society:

b) societies, groups or laboratories organized or existing under the laws of the State of their incorporation or of their seat and which, in the Council's opinion, make a significant contribution to European science;

c) individuals who are members of a society or group which has been accepted as an Ordinary Member of EPS and who fulfil the conditions laid down in the foregoing paragraph provided such individual membership in EPS is not precluded by the Constitution or by-laws of their society or group.

d) individuals who are members of a society or group which is not an Ordinary Member, Category $4 b)$ but has been approved by Council as a Collaborating Society.

(A Collaborating Society will normally be located outside Europe.)

ARTICLE 16

The Council shall be composed in the following way:

a) delegates or representatives appointed by participating societies, groups or laboratories mentioned in Article 4 , paragraph b),

b) delegates or representatives elected in accordance with the by-laws by individual members of categories a), c) and d) mentioned in Article 4,

c) all chairmen of Divisions

(Details of the relation between number of representatives and number of members are omitted as no changes have been made.)

\section{By-Laws}

RULE 1

Individuals applying for ordinary membership shall do so on the standard application form, which shall be signed by two. Individual Ordinary Members, by two fellows, or by two members of the governing body of a society, group or laboratory which is an Ordinary Member of the Society or a Collaborating Society.

RULE 19

Representatives on the Council of the Individual Ordinary Members - Constitution Article 4a), c) and d) - shall be elected by ballot from a list, provided by the Secretariat, of all nominations signed by at least three Individual Ordinary Members or Fellows..

(Further administrative details which are unchanged are omitted.)

RULE 35

Ordinary Members shall pay annual fees as follows:

a) Individual Ordinary Members, Constitution Article 4a) 14 units/IOM 1

c) Individual Ordinary Members, Constitution Article 4c) 4 units/IOM

d) Individual Ordinary Members, Constitution Article 4d), Such number of units as decided by who are thus also members of a Collaborating Society. Council for each Collaborating Society. 2

(Details of the scales applying to $4 \mathrm{~b}$ ) are unchanged and are omitted.)

1) Council approved by a large majority the raising of the unit fee from Sw.Fr. 9. - to Sw.Fr. 10. - to come into effect after 31 December 1982, when the Executive Committee considered that inflation in Switzerland and/or the balance sheet of the Society justified an increase. To take effect at the same time the annual fee to $4 a$ ) members will be reduced from the current 14 units to 12 units.

2) Council unanimously agreed that the American Physical Society should be given the status of Collaborating Society and set the annual fee for members of APS at 5 units (for 1982, Sw. Frs. 45. - or $\$ 25,-$ ).

RULE 36

Fellows shall pay as Individual Ordinary Members, Rule 35a), c) or d).

\section{Atomic and Molecular Physics}

Council approved the change of title of the former Atomic Physics Division to Atomic and Molecular Physics Division to take immediate effect. The change was recommended to Council at its meeting in Istanbul by the Chairman of the Division.

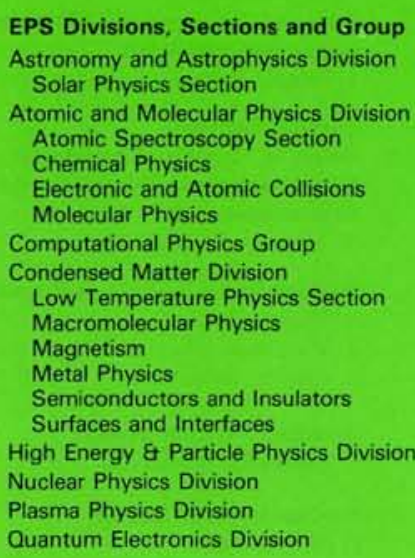

Europhysics News is the official journal of the European Physical Society which comprises 29 National Societies, Academies and Groups, over 3000 Individual Members and 32 Associate Members. Governing bodies of EPS are the General Meeting. Council and an dies of EPS are the General Meeting, Council and an policy. EPS promotes the collaboration of physicists throughout Europe and encourages all aspects of international exchange in physics. EPS administers scholarnational exchange in physics. EPS administers scholar-
ships awarded for research and studies in different ships awarded for research and studies in different countries and a "teaching abroad" scheme. EPS publishes in addition to EN, Europhysics Conference Abstracts, E. Ed. News and, in collaboration with The
Institute of Physics (UK), the European Journal of Physics. Individual Members receive EN free of charge (price to institutions: Sw. Fr. 82,-/a), rebates on the price of many publications and on conference fees. Annual subscription to EPS from individual Members who belong to one of the EPS member societies is: Sw. Fr. 36. - ; for independent members: Sw. Fr. 126. - .

\section{Editor: E.N. Shaw}

Meetings Compilation: W.S. Newman

Editorial Board:

K. Appert, A. Baratoff, G.J. Béné,

G.R. Macleod, A. Maeder, J. Muller

Editorial and Advertising Office at the EPS Secretariat.

Address: EUROPEAN PHYSICAL SOCIETY

P.O. Box 69,

CH-1213 Petit-Lancy 2

Switzerland

Telephone: Geneva (22) 931130

Telex: $23 \mathbf{4 5 5}$ alarm ch

Cables: europhys genève

Printed by: Pfirter frères SA

CH-1213 Petit-Lancy/Switzerland 